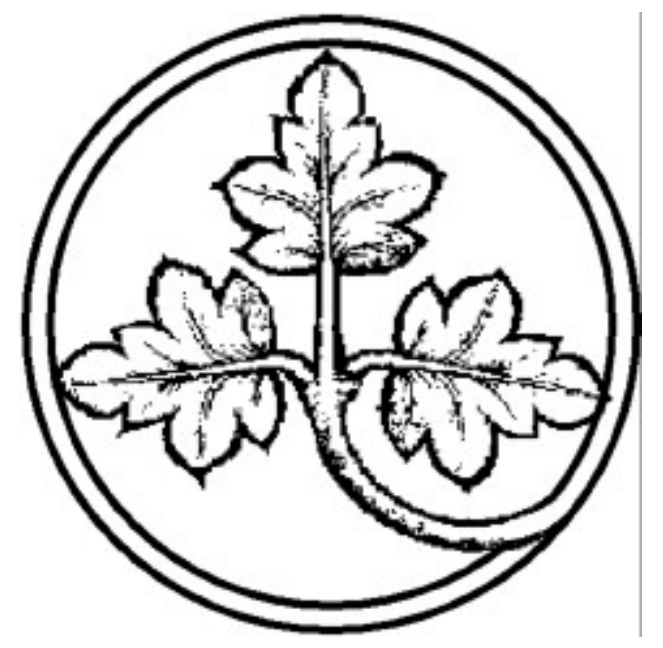

Gemeinschaftsgüter: Recht, Politik und Ökonomie

\author{
Pre rints \\ aus der Ma Planck Projektgru e \\ Recht der Gemeinschaftsgüter \\ onn
}

A Snowball against Global Warming: An Alternative to the Kyoto Protocol

von

Marco Verweij 


\section{A Snowball against Global Warming: An Alternative to the Kyoto Protocol}

Marco Verweij

August 2001

Max-Planck-Projektgruppe Recht der Gemeinschaftsgüter, Poppelsdorfer Alle 45, 


\section{The Problem and the Solution}

In July 2001, in Bonn, environment ministers of more than thirty countries claimed that they had just made a "first step" towards ratification of the Kyoto Protocol. The original, 1997 version of this Protocol had called upon industrialised countries to reduce their contributions to global warming by 5.2\% between 2008 and 2012 (as compared to 1990). Last July, creative accounting on part of the international negotiators cut that commitment by more than half. This compromise (the "first step") was supposed to make implementation of the Kyoto Protocol easier to achieve, and hence more palatable, for Japan, Australia and Canada. Without the continued participation of these three countries, ratification of the Protocol would have become impossible. Despite the upbeat press reports around the globe, it is not at all certain whether the compromise struck in Bonn will indeed clear the way for the ratification of the Kyoto Protocol. Ratification of international treaties needs to be undertaken by parliaments, not governments. The parliaments of Australia, Canada and Japan could still overrule their governments. Moreover, many cumbersome and divisive "technical issues" remain to be settled at future international conferences, each of which could easily unravel the Protocol even at this late date. And then there is the problem that both the United States Senate and the Bush Administration have steadfastly refused to abide by the Kyoto Protocol. Officially, the Kyoto Protocol can be ratified without the United States. Still, the United States is by far the largest contributor to global warming - it alone is responsible for about a quarter of the problem. The compromise that was agreed upon in Bonn will only add up to any reduction of the contribution of industrialized countries to the problem of global warming, if the United States will somehow honour the Kyoto Protocol. This is a rather optimistic premise, as both the American government and Senate have not wavered in their opposition to the treaty, and as the American contribution to global warming has been rapidly rising in recent years. The arduous road to Kyoto illustrates the ineffectuality of the present approach to curbing global warming. But the problems of the Kyoto Protocol extend beyond the recurring inter-governmental squabbles over whether, and how, to implement the document. Even if the original, undiluted version of the Protocol had been

\section{ACKN OWLEDG EMEN TS}

I would like to thank Raimund Bleischwitz, Christoph Engel, Archon Fung, Frank Hendriks, Adrienne Héritier, Alkuin Kölliker, Barbet Punt, Michael Thompson and Jan Zielonka for their insightful comments on an earlier version of this preprint. I presented the paper at The International Institute for Applied Systems Analysis on 19 January 2001, and at a UCLA conference entitled "Biopiolitics: Rational Choice Is Nearly D ead" on 31 March 2001. I am grateful to Joanne Bayer and Susanne Lohmann for having invited me to IIASA and UCLA, respectively, and to the participants in these meetings. I am also indebted to Tom Heller for several stimulating discussions on the topic of this paper. 
implemented in full, it would still not have made any difference to the world's climate. Only a radically different approach to international decision-making can save the world from overheating. In this essay I describe why this is so, and what this approach would look like.

Global warming is the international environmental problem from hell. It poses the gravest of ecological risks, and compiles all known hurdles to international environmental agreement. But first a crash course. ${ }^{1}$ When the rays of the sun hit the face of the earth, heat is produced and rises up towards the sky. By burning fossil fuels, and undertaking other activities, we send a number of gases into the atmosphere that trap this heat close to earth. Over time, this causes the average temperature on our planet to increase. Fossil fuels include oil, coal, and natural gas. As a consequence, most human uses of energy contribute to global warming. When powered by fossil fuels, then driving a car, operating a plant, and heating and lighting a building, will all make the world warmer. For good measure, a number of agricultural activities also add to this greenhouse-effect. Methane, for instance, is a powerful greenhouse gas that is produced in the stomachs of goats, sheep and cattle, as well as by various ways of growing rice.

Human-induced global warming carries great risks. Warmer water takes up more space. A rise in global temperature will therefore lift the sea-level. This process will be accelerated by a melting of the ice-caps on the South Pole. As a result of the rising sea-level, small islands and low-lying coastal regions may become submerged. Rivers, lakes and groundwater will become saltier, which will threaten local agriculture. Equally important, an increase of the average temperature on earth will disrupt regional climates. Some parts of the world will get hotter, some colder, some rainier, some drier. But each climate will be affected. Not all plants and trees are able to migrate as fast as the world's climates will. Widespread destruction of flora and fauna, and further loss of farmland, may therefore follow from climate change. A wider spread of tropical diseases, such as malaria, can also be expected, as can an increase in storms and hurricanes in various parts of the world.

On top of all this, global warming might unleash forces that threaten life on a continental or even planetary scale. For instance, it might disturb the Gulf Stream that flows from the Gulf of Mexico Northeast across the Atlantic O cean and that keeps Western Europe from freezing over. And no one knows for sure whether even a relatively small amount of global warming will not trigger an unstoppable, self-sustaining rise in global temperatures, turning Earth into a sister planet of Venus.

Given these grave threats, it is maddening to realise that the problem of global warming rolls into one package nearly all of the obstacles to international environmental cooperation that are laid out in

1 A clear introduction is S. George Philander, Is the Temperature Rising? The Uncertain Sciene of G lobal W arming (Princeton, NJ: Princeton University Press, 1998). 
the textbooks. ${ }^{2}$ For a start, there is lingering scientific uncertainty over the causes and effects of climate change. Although it is increasingly clear that global warming is occurring, there is still a bit of room for arguing that climate change is not taking place, or at least that it will not be as detrimental as is commonly assumed. This lingering uncertainty has fired up opponents of international collaboration on global warming. ${ }^{3}$

Another factor that hampers international action on global warming is that it is caused by so many different human activities taking place all over the world: it is a "problem of many agents". This leads to the idea that it may be quite costly to slow down global warming. ${ }^{4}$ It also leads to the view that this is a global threat that can only be warded off by close cooperation between all countries of the world. Yet, there are very few (if any) expensive and truly universal accords in place.

It also does not help that in the short term global warming is a rather invisible process. There is a considerable time-lag between the causes and effects of climate change. Greenhouse gases that are being released at present will affect our climate in 20 to 50 years time. Inter-governmental environmental action is typically triggered by a highly visible and widely publicised ecological disaster, such the oil spill from the Exxon-Valdez or the havoc wreaked upon the German forests by acid rain. Due to the time-lag between causes and effects, no such "luck" can befall the efforts to curb global warming.

To top things off, there is the North-South stalemate. The governments of the Southern countries have a solid case. They point out that the Northern countries have thus far been responsible for the overwhelming majority of greenhouse gas-releases - thus unilaterally inflicting environmental damage upon poor countries. Moreover, Southern countries have to cope with other, more pressing environmental problems that are much less of an issue in the North (such as soil erosion and the availability of drinking water). And, of course, the people living in poor countries have fewer resources with which to slow down, and adapt to, climate change. Hence, Southern governments

2 E.g., Oran A. Young and Gail Osherenko, 'International Regime Formation: Findings, Research Priorities and Applications', in O ran A. Young and G ail O sherenko (eds), Polar Politics: Creating International E nvironmental Regimes (Ithaca, NY: Comell University Press, 1993).

3 The latest study to question the link between global warming and carbon dioxide emission is Jan Veizer, Yves Godderis and Louis M. Francois, 'Evidence for Decoupling of Atmospheric $\mathrm{CO}_{2}$ and Global Climate during the Phanerozoic Eon', N ature (Vol. 408, No. 6813, December 2000), pp. 698-701. Among other organisations, the National Center for Policy Analysis has used such studies to argue that no climate change problem exists. See for instance, H. Sterling Burnett, 'The Collapsing Scientific Cornerstones of Global Warming Theory', Brief A nalysis N 0. 299 (D allas, Texas: National Center for Policy Analysis, June 1999). A whole range of frequently updated critiques of the global warming-thesis can be found at: http:/ / www.ncpa.org/ hotlines/ global/ gwhot1.html.

4 For example, one recent study puts the minimum costs of stabilising atmospheric $\mathrm{CO}_{2}$ concentrations at US $\$ 550$ trillion and the maximum costs at US\$ 940 trillion. (These costs are meant to be the total costs for the whole world over the period 1990-2100, and are stated in 1990 prices). R. Alexander Roehrl and Keywan Riahi, 'Technology Dynamics and G reenhouse Gas Emissions Mitigation: A Cost Assessment', Technological F orecasting and Social C hange (Vol. 63, 2000), p. 250. 
have argued that it would be unfair to require them to make any immediate contributions to the prevention of global warming. In their opinion, the North should first cut its own emissions, while enabling the Southern countries to acquire climate-friendly technology. The Northern countries, meanwhile, point out that any reductions in their emissions would be rendered entirely ineffectual if countries such as China, India and Brazil did not curb the growth of their emissions of $\mathrm{CO}_{2}$ and other greenhouse gases. Especially the U.S. Senate, and the Bush-Cheney Administration, have refused to endorse any international agreement that would not also legally bind Southern countries to keep the increase of their emissions within bounds.

Given these trials and tribulations, it is remarkable that the inter-governmental negotiations on the 1992 United Nations Framework Convention on Climate Change (UNFCCC) have advanced a little bit. Despite the extraordinarily difficult circumstances, some tiny progress has been made. Since 1997, the representatives of 84 states have signed the Kyoto Protocol to the UNFCCC. ${ }^{6}$ The Kyoto Protocol binds "Annex I" countries (basically the member-states of the OECD, minus Mexico, but plus the Eastern European countries) to reduce the 1990 level of their greenhouse gas-emissions by 5.2\% between 2008 and 2012. The Protocol also allows countries to engage in emissions-trading (i.e., paying for emission reductions in other parts of the world to meet one's international obligations). Moreover, it instructs Annex I states to assist poor countries in acquiring climatefriendly technology.

However, although the Kyoto Protocol has been signed by 84 countries, thus far it has been ratified by a mere 30. As a consequence, it has not yet come into force. The international conferences in The Hague in November 2000, and in Bonn in July 2001, aimed to bring the Protocol closer to ratification through settling a number of remaining issues. One such issue was the extent to which countries could off-set their emissions of greenhouse gases by preserving their forests and agricultural lands. Trees and certain soils soak up carbon dioxide from the air, and thereby curb global warming. It could therefore be argued that preservation of these so-called "carbon sinks" (i.e., not cutting down trees) contributes to preventing global warming. In Bonn, it was agreed that Japan, Australia, Canada and other countries could count preservation of existing trees and soils towards their reduction goals. This is of course hardly an effective course of action, as these countries have harboured few plans to cut their forests anyway. This form of creative accounting has in effect lowered the commitments of industrialized countries to a $1.8 \%$ cut in their collective emissions of

$5 \quad$ Thomas Schelling builds a compelling case for this normative position in his essay "The Cost of Combating Global Warming', Foreign A ffairs (Vol. 76, November/ D ecember 1997), pp. 8-14.

6 The text, and present status, of the United Nations Framework Convention on Climate Change, and its Kyoto Protocol, can be found at: http:/ / www.unfccc.de/ resource/ convkp.html. 
greenhouse gases. ${ }^{7}$ And this figure assumes that the United States will ratify the Kyoto Protocol (or will at least enact its obligations under the Protocol). But in April 2001, recently appointed U.S. President Bush closed the door on any American participation by labelling the Protocol as too expensive and unfair to the United States. Last, although barely noticed in the media, the conference in Bonn did not produce a final legal text that governments could submit for ratification to the parliaments of their countries. Various controversial issues (for instance regarding how to engage in international emissions trading) were not settled in Bonn. It is not at all clear whether the governments involved will be able to reach consensus on these complex problems. So even though the environment ministers claimed to have achieved a breakthrough on some issues (in particular carbon sinks and enforcement), it remains to be seen whether even this watered-down version of the Protocol will come into force.

Despite all the consternation in The Hague and the elation in Bonn, it does not really matter whether the Protocol can be rescued or not. The policy measures envisaged in the Kyoto Protocol are wholly insufficient, well-nigh impossible to implement, not sustainable, as well as too costly. Even if the Protocol were eventually ratified, it would not prevent much global warming.

The cutbacks in emissions stipulated by the Kyoto Protocol are so small as to be well-nigh insignificant. Almost all the involved scientists believe that a reduction of some $50 \%$ in the worldwide release of greenhouse gases is needed by 2050 in order to stabilise the world's climate at the end of the century. Even if the original version of the Kyoto Protocol was fully implemented, then, by 2100 , only $8 \%$ would have been chewed off of a "business-as-usual" scenario in which greenhouse gas emissions would quadruple in the next 100 years. At this snail's pace, we would need another 30 Kyoto Protocols to stop global warming. ${ }^{8}$ And that would only be the case, if all these protocols were actually implemented by the involved parties. At present, few countries are on their way to meeting the tiny requirements of the first of these 30 needed Kyoto Protocols. In the United States, emissions have actually gone up by more than $10 \%$ since $1990 .{ }^{9}$ In sum, the Kyoto Protocol has not yet been ratified, and its goals are not being met, while it only asks for insignificantly small reductions from Northern countries, and does not impose anything on Southern countries. Not exactly a stunning success.

\footnotetext{
7 See for instance Eric Pianin, 'Emissions Treaty Softens Kyoto Targets: Environmentalists' Euphoria over Global Pact Gives Way to D ebate on Concessions', W ashington Post, July 29, p. A23.

8 David Malakoff, 'Thirty Kyoto Protocols Needed to Control Warming', Science (Vol. 278, December 1997), p. 2048.

9 This can be read from the website of the U:S. Environmental Protection Agency: http:/ / www.epa.gov/ globalwarming/ emissions/ national/ trends.html.
} 
The Kyoto Protocol is also quite cumbersome to implement. Its foresees international trading of permits to emit greenhouse gases. This scheme would require continuous monitoring and complex calculations. If for instance a firm in the United States wanted to fulfil its obligation to reduce the emission of greenhouse gases by paying Brazilian authorities to reforest a part of the Amazon basin, then that would involve the following calculations: (1) estimation of how many greenhouse gases, and how much of each, the firm is putting into the air; (2) assessment, on the basis of the legal standards, of the amount by which the firm needed to lower its emissions; (3) the subsequent establishment of how many trees, and what kinds of trees, would have to be planted in order to meet the company's targets - given current scientific uncertainties, a highly controversial task. Moreover, all these actions would have to be monitored. In other words, just to reduce the contribution that a single firm makes to the greenhouse effect would, under this system of emissions-trading, already be fraught with difficulties and controversies. These would grow exponentially if this mechanism became available for all the firms in the industrialised world. Besides being rather unambitious, the Kyoto Protocol is therefore quite impractical. ${ }^{10}$

Furthermore, it is doubtful whether the work that is needed to turn the Kyoto Protocol into a success could ever be sustained or expanded. This is because its implementation depends on the continued willingness of a very large number of governments to cooperate. Its supporters have defended the Protocol as a "first step". But that first step has still been not been concluded nine years after the UNFCCC was agreed upon, and subsequent steps may actually be harder to make than this first one. Further steps would necessarily have to include the United States (as the largest current emitter of greenhouse gases) as well as developing countries (as their emissions may rapidly rise in the near future). But almost all developing countries have refused to accept the slightest hint of future obligations, whereas the United States Senate has stated time and again that it will not support any treaty that leaves developing countries off the proverbial hook. And even all these disagreements could miraculously be overcome at a certain point in time, then it would merely take a change of heart among China's rulers, or an economic downturn in Europe, to put the whole intergovernmental process at risk again.

10 A similar warning is issued at the end of a detailed evaluation of the positive role that pollution permits have played in the U.S. efforts to reduce acid rain: A. D enny Ellerman, Paul J. Joskow, Richard Schmalensee, JuanPablo Montero and Elizabeth M. Bailey, Mark ets for Clean A ir: The U.S. A cid Rain Program (Cambridge: Cambridge University Press, 2000), pp. 321-22. To fully grasp the enormous problems that will bedevil any efforts to engage in greenhouse gas emissions-trading, see also Matthias Jonas, Michael Obersteiner and Sten Nillson, 'How to Go from Today's Kyoto Protocol to a Post-Kyoto Future that Adheres to the Principles of Full Carbon Accounting and Global-Scale Verifications', Interim Report IR-00-61 (Laxenburg, A ustria: International Insititute for Applied Systems Analysis, November 2000). In his book The Collapse of the Kyoto Protoool and the Struggle to Slow G lobal W arming (Oxford: Oxford University Press, 2001), David Victor also offers a variety of practical arguments against international emissions-trading. 
Last, but certainly not least, the Kyoto Protocol is too expensive, in that it is not centrally concerned with the development of new technologies and energy resources that might bring down the costs of combating global warming. True, there has been some lip-service. The Convention urges the Northern countries to "promote, facilitate and finance" a technology transfer to the South. The Intergovernmental Panel on Climate Change (IPCC) has published a report on how to do this. ${ }^{11} \mathrm{But}$ nothing else has been undertaken. More damagingly, the main policy instruments that have been discussed at the international negotiations do nothing to speed up the development and use of climate-friendly technologies.

The "command-and-control" policies that were until quite recently preferred by the European Union are notorious for not stimulating technological change. At best, these policies instruct firms to buy the greenest existing technology. But they do not spur companies on to use their knowledge and creativity in a risky effort to develop novel technologies and energy resources that are both profitable and emit less greenhouse gases.

Contrary to popular belief, it is not at all clear whether "emissions-trading" (championed by the Clinton Administration, and recently accepted by the European Union) fares much better. Emission-trading may perhaps allow reductions of greenhouse gases to occur in those place where they cost least. But it may not promote much technological improvement. Proponents have argued that emissions trading will stimulate technological change by making it more profitable for firms to develop and use cleaner technologies and energy resources. ${ }^{12}$ Opponents have argued that such a scheme will not lead to technological breakthroughs. In their eyes, it would only entice large, profitable corporations that emit a lot of greenhouse gases to buy off their pollution by acquiring extra permits, rather than to commit themselves to the more slippery slope that may lead to technological innovation. Having paid a lot of money for extra pollution permits, companies will be less inclined to take on the risks involved in developing and applying cleaner technology. The empirical evidence on this question is actually mixed. ${ }^{13}$ In any case, the point is rather moot given the many implementation problems that make trading in permits to release greenhouse gases wellnigh impossible to achieve.

11 Intergovernmental Panel on Climate Change, 'Methodological and Technological Issues in Technology Transfer', A Special Report of IPCC Working Group III (G eneva, 2000). Available at: http:/ / www.epa.gov/ globalwarming/ emissions/ national/ trends.html.

12 The trading solution has received a lot of backing from the business community. Among environmental organisations, two prominent supporters are Environmental Defense Fund and the Pew Center on Global Climate Change. Among the negotiating countries, the so-called "Umbrella Group" (consisting of the USA, Japan, New Zealand, Australia and Canada) has advocated unfettered emissions-trading. A recent study that comes out in favour of permit-trading is Jae Edmonds, Michael J. Scott, Joseph M. Roop and Christopher N. MacCracken, International E missions \& G lobal Climate Change (Washington, DC: Pew Center on Global Climate Change, 1999). 
To summarise, we have now had nine years of protracted diplomatic battles (mostly fought out by people with the best of intentions) to produce a fragile and inadequate treaty on global warming that has not been, and probably will never be, ratified or implemented. Has all of this been in vain? No, the international negotiations have greatly raised people's awareness of the threat, and this is a vital pre-condition for any solution to global warming. Still, for two reasons the Kyoto Protocol and the UNFCCC represent a deeply flawed approach to fighting global warming. It is important to identify those reasons as they also offer the key to a real solution.

First, the problem of global warming, as currently perceived, is simply too difficult to solve. Governments are asked to legally bind themselves to imposing high costs on their citizens and companies in a co-ordinated attempt to stem an uncertain environmental threat from probably happening in the not-so-near future. And all of this while a great many of these governments also have to deal with other, much more pressing environmental challenges, and have very few resources to draw on. As long as the issue of climate change is defined in these terms, it will not be solved. The fatal flaw of the UNFCCC is that it does not alter this conceptualisation of the problem.

Second, formal, top-down, inter-governmental negotiations involving some 180 nation-states are not exactly a speedy and reliable vehicle for bringing any environmental issue to a close - let alone the Mother of All Environmental Issues. The UNFCCC is a typical example of the traditional diplomatic route to international agreement. Along this route, the diplomatic missions of the involved countries must first agree on, and sign, an official treaty. Thereafter, the treaty needs to be ratified by the parliaments in all involved countries. Only when a large number of such ratifications are in can the treaty enter into force. Then the process of monitoring starts. Usually, this legalistic route to international policy is a painstakingly slow process. Moreover, official ratification of international agreements tends to make the negotiating teams quite edgy as to the precise language used in treaties. This approach also assumes that both the governments and parliaments of more than 180 highly diverse countries can agree on the solution to a deeply complex, and perhaps costly, future ecological threat. Furthermore, it assumes that, once governments have agreed on international measures, they will actually be able to impose their will on the myriad of producers and consumers within their countries. These are shaky foundations indeed. In comparison, Sisyphus's chances of success looked much brighter.

13 David Wallace, Environmental Policies and Industrial Innovation: Strategies in E urope, the USA and Japan (London: Earthscan, 1995), p. xx. 
These two arguments reveal what a realistic solution to the threat of global warming would look like. We need to develop and apply novel technologies and energy resources that do not emit greenhouse gases (and, where possible, solve other environmental problems as well) and that are also cheaper than existing technologies and energy resources. International cooperation should not be overly formal, and should be concerned first and foremost with stimulating such technological change. In the rest of this article, I will argue why this is feasible, how it can be done, and what role international coordination should play. For the moment, please suspend your disbelief, and consider the advantages that this plan would bring if it were achievable.

The proposal is "Y 2K (debacle) proof". Even if it turned out that the present concerns over climate change were greatly exaggerated, then the development of cleaner and cheaper technologies and energy resources would still be beneficial. A part from the obvious economic advantages, this scheme would lessen the world's dependence on the oil-producing countries (as substitutes for fossil fuels would become economically attractive). Plus, increased use of alternative forms of energy would often help out with solving other environmental problems, such as acid rain and water pollution. ${ }^{14}$ If feasible (and you have agreed to suspend your disbelief momentarily), then this would be a noregrets policy.

Furthermore, my proposal would meet all the basic objections that have been made by the diplomatic teams of the United States, the European Union and the developing countries. The United States has continuously complained that the costs of curbing climate change are too high. This is why the American negotiators have insisted on creating international markets in pollution permits - these are supposed to lower the costs of curbing global warming. My plan would assuage these concerns in another way. It would involve an all-out effort to make the fight against the greenhouse effect profitable by lowering the costs of energy.

The European Union, in its turn, has balked at the creation of international markets for emission permits. The many monitoring problems that are involved in the creation of such markets have made the European governments wary of such a scheme. Moreover, they have argued that countries have a moral imperative to clean up the mess that they have made within their own borders. In Bonn, the European Union grudgingly accepted a more widespread use of international emissionstrading, as this was the only way in which it could prevent the governments of Japan, Australia and Canada from following President Bush's rejection of the Kyoto Protocol. My proposal side-steps this whole issue, as it does not predominantly rely on international emissions-trading.

14 D aniel Sarewitz and Roger Pielke, Jr., 'Breaking the Global-Warming Deadlock', The A tlantic M onthly (Vol. 286, No. 1, 2000), pp. 54-64. 
The leaders of the developing countries, for their part, have rightly pointed out that most greenhouse gases have been released within rich countries, and they have protested about the environmental damage that the Northern states have thus unleashed upon the South. These governments have also argued that they are too poor, and have to deal with too many other environmental threats, to be able to contribute significantly to any solution of the climate changeissue. If the Northern countries want to prevent the economic growth in the South from contributing massively to global warming, then the former had better start paying up. This proposal pre-empts these objections as well. Almost all R\&D (Research and D evelopment) efforts concerning the production and use of energy occur within a handful of countries: the United States, Japan, Germany, the United Kingdom, France, Italy, Canada, Switzerland and the Netherlands. ${ }^{15}$ Therefore, any drive to develop cleaner and cheaper energy resources would have to be initiated within these affluent countries. For one thing, they would have to invest much more public and private funds into energy $R \& D$. If these R\&D efforts were successful, then the producers and consumers of the developing countries could benefit from this as well, of course. This would be the case if a technology transfer to the South took place; in other words, if the developing countries were able to leap-frog to the latest technologies. Putting more money and effort into energy R\&D, as well as stimulating the spread of cheaper energy resources within the South, would be one way in which the rich countries could compensate the poor countries. Another would be by helping developing countries to set up their own energy R\&D centres. In these ways, my proposal also caters to the wishes of the Southern states.

This plan would also ease the existing diplomatic tensions by greatly reducing the number of states that have to give their consent to any final deal. In The Hague an impossibly large number of governments were negotiating with each other. My proposal calls for the spread of technologies and energy resources that are both cheaper and cleaner. A major (but certainly not the only) part of this effort has to come from increased $R \& D$ in the field of energy. Since only 9 countries are at present carrying out more than $95 \%$ of the world's energy $R \& D$, my plan would trim the number of involved governments to more reasonable proportions. Of course, the international efforts should not be limited to these 9 states. Other affluent countries should join the fray, including the newly industrialised countries (such as Singapore and South Korea). Developing countries with fastgrowing economies (such as India and China) should start up their own facilities for energy research, and should also play their international parts. But this still leaves a rather limited number of

15 James J. D ooley, Paul J. Runci, and Esther E. Luiten, 'Energy R\&D in the Industrialised World: Retrenchement and Refocusing', Interim Report PNNL-12661 (Richland, Washington: Pacific Northwest National Laboratory, 1998). 
countries that would have to be involved in an international agreement on global warming that would focus on technological change.

Moreover, not one of these countries, not even the United States, would be absolutely vital for this international cooperation. A policy that stimulates the search for production processes and for forms of energy that are cheaper and cleaner mixes public with private goods. Its public goods aspect would mean that part of its benefits will accrue to the people who have not pitched in. Lower energy prices and fewer greenhouse gases would benefit all, including those who have not contributed to climate-friendly technology. Free-riding, from a Northern perspective; the repaying of a historic debt so far as the South is concerned. But, either way those countries and companies that have been at the hub of the efforts to stimulate technological change would benefit more than the states and firms that have chosen to remain at the sidelines. In the field of energy there is a clear "first-mover advantage". If, for instance, British Petroleum and Shell were successful in their present search for renewable energy-resources that are economically viable, then they would enjoy a tremendous advantage over their slacking competitors in the world's energy markets. This competitive edge would also benefit the citizens of the various countries in which these companies have their main offices somewhat more than the populations of other places. (An increased marketsize of Shell would bring more jobs and tax revenues to London and the Netherlands than to Texas. A growth of Texaco would do the opposite.) Two things follow from this. If a country or enterprise decided not to support climate-friendly technology, then it would not undermine the collective enterprise. Furthermore, governments would be foolish not to climb on board. In effect, my plan kills three birds with one stone: it greatly reduces the number of states that would have to be involved in international cooperation on global warming; it avoids making such cooperation dependent on the continued support of any of these countries; and it provides strong incentives for each of these states to contribute.

In addition, my proposal would do away with much of the debilitating formality of the ongoing inter-governmental dealings. A focus on technological change would not require such a formalistic approach to international policy. What would be needed most is a pledge to promote climatefriendly technology. This can be done through increasing national $R \& D$ budgets, adapting infrastructure, shifting taxes and subsidies, engaging in a dialogue with firms and citizens' groups, and the like. These actions would be highly practical, and none of them would have to be officially ratified or strictly monitored. An international commitment to swiftly reducing the release of greenhouse gases would also be helpful. But it would be important not to make this commitment legally binding on countries. The haphazard, intermittent nature of technological development would not allow for that. 
Last, this plan would make "technology transfer" a much more feasible option. As presently conceived, technology transfer is very much a top-down undertaking. Present plans call for estimates of the future "technological needs" of developing countries, ${ }^{16}$ as well as assessments of how much these countries should receive in compensation for using the latest clean technology. ${ }^{17}$ Again, this seems a rather dubious and overly technocratic project. If cheaper and cleaner energy resources and technologies became available, then the governments and companies in the South would have a strong incentive to acquire these themselves. Of course, such technological progress would not be a panacea for the spread of cleaner practices. It would not make the adoption of new technologies and energy resources by Southern companies automatic and instant. There would still be a role for governmental action, in the form of capacity-building, demonstration projects, spreading the word, adapting institutions and infrastructure and so on - both in the South and in the North. But the diffusion of clean technology would certainly be a lot easier under this scheme, because it would be in the financial interest of companies and governments everywhere to employ the latest technology.

By now, I hope to have established that without widespread technological progress, it will be wellnigh impossible to curb global warming through international action (or, for that matter, through any kind of action). With such progress, halting global warming would not be ensured, but it would certainly be a great deal easier. This leaves a couple of big questions hanging in the air. Is it possible to develop new technologies and energy resources that do not emit greenhouse gases and that are cheaper than existing alternatives? And if that were indeed the case, then how could international cooperation contribute to the development and spread of climate-friendly technology? An excursion to the Rhine river in Western Europe, and several other successful cases of environmental protection, will allow us to discern the answers to these pertinent questions.

\section{Cleaning up Their Act}

In the early 1970s, the Rhine (which flows from Switzerland through France and Germany before scattering all over the Netherlands) became widely known as the "open sewer of Europe". Since then, a major clean-up of the river has taken place. ${ }^{18}$ Nowadays, the river is hailed as the cleanest major waterway in Europe. Its restoration is being touted as a model for water protection efforts around the world. What makes the clean-up of the Rhine so instructive is that some $18 \%$ of the world's chemical industry is located on its banks. A major feature of its restoration has been the

16 See the IPCC special report on technology transfer, op. cit., in note 11.

17 Heather Ross, 'Changing the Market Climate for Emissions Trading', W eathervane: A Digital Forum on G lobal Climate Policy (19 A ugust 1998), available at: http:/ / www.weathervane.rff.org.

18 This part of the text is based on Marco Verweij, Transboundary Environmental Problems and Cultural Theory: The Environmental Protection of the Rhine and the G reat Lakes (New York and London: Palgrave, 2000). 
investments in water protection undertaken by the large chemical companies along the river. Their environmental measures have consistently surpassed the domestic legal standands and international norms that have pertained to the Rhine..$^{19}$ In the early 1970s, it was no longer possible for companies to deny that the Rhine had become extremely polluted. The river had turned yellow in places, had a foul smell, and dead fish regularly washed up on its banks. Under pressure from government departments, environmental groups and its own employees, the large chemical concerns (such as Hoechst, BASF, and Bayer) started to take environmental action. They went about this in a dynamic fashion, as if conquering a new market. These companies first set themselves ambitious targets for pollution reduction, and then developed the means and technologies that allowed them to reach those targets. In doing this, the chemical concerns along the Rhine took a risky approach that was the inverse of the command-and-control policies championed by the authorities. Government policies merely required firms on the Rhine to use the best available technologies for reducing water pollution. By contrast, a number of these corporations revolutionised wastewater treatmenttechnology, making possible reductions in water pollution that had hitherto been unthinkable. (Bayer is now selling its wastewater treatment technology around the world.) This does not mean that the many actions of government departments and environmental organisations have been superfluous. Civic action, government policies and international treaties have kept the chemical firms along the Rhine on their toes. Yet, it was the innovativeness and risk-taking of these companies that made the rapid restoration of the Rhine possible.

One major lesson can be drawn from this remarkable success story. Once firms become convinced that they are creating serious environmental harm, and decide to do something about it, they are able to solve environmental problems much swifter and more comprehensively than environmental agencies can ever dream of. It is their innovativeness, their willingness to accept risks, their financial resources, their intimate knowledge of their own production processes, and their vast technological expertise that allow companies to do this. The main aim of international cooperation on global warming should be to harness this creativity and boldness. There is one catch, though. The clean-up of the Rhine has certainly not been costless. The chemical companies along the river have invested billions of dollars in pollution reduction. But, even so, these firms have always remained quite profitable and competitive.

When it comes to fighting global warming, many opportunities to create "win-win" situations abound. A lot of money can instantly be saved through increasing energy efficiency. In 2000, two of the world's largest environmental organisations have each started to work with an assortment of

19 Thomas Bernauer and Peter Moser, 'Reducing Pollution of the River Rhine: The Influence of International Cooperation', The Journal of Environment and D evelopment (Vol. 5, No. 4, 1996), pp. 389-390. 
enterprises that want to reduce their emissions of greenhouse gases, as well as their energy bills. In each case, the environmental organisation provides firms with the latest know-how on how to save energy, and works with the companies to tailor this knowledge to their particular circumstances. In return, the environmental organisation is allowed to apply the lessons thus learned in its work with other firms. It also offers an independent assessment of the cutbacks in greenhouse gases that have been achieved by the corporations, as well as free publicity. Some 8 major companies from North America and Western Europe have pledged Environmental D efense to cut back their emissions in this way. Other major corporations have signed up to a similar program run by the World Wide Fund for Nature. These enterprises are already environmental leaders within their diverse packs. Moreover, they have committed themselves to cutbacks that match or surpass the goals set out in the Kyoto Protocol. Households too can spare the climate and their purses by doing such simple things as switching to double glazing and fluorescent light bulbs.

In agriculture, various ways exist in which to make money by cutting back the emission of greenhouse gases. A more diverse diet for goats, sheep and cattle, as well as greatly reducing their release of methane, would also increase their production of milk. And by growing more crops within rice fields, farmers can increase their production and income, while lowering their contribution to the greenhouse effect.

Renewable energy resources, such as solar, water and wind energy, offer further opportunities to turn the fight against global warming into a lucrative business. ${ }^{20}$ Their prices have come down considerably in recent years. ${ }^{21}$ At this very moment, wind energy stands poised to become fully competitive. State-of-the-art wind plants currently produce electricity at about \$0.05 per kilowatt hour, or six times more efficiently than was the case in 1980. This means that only the breadth of a hair now separates the costs of wind energy from the expenses incurred when using other forms of energy $^{22}$. And expectations are that the costs of wind energy will fall by another 20-30\% in the next three years. ${ }^{23}$ Even the International Atomic Energy Agency has been forced to admit that wind energy will very soon be fully competitive in the strictest economic sense with fossil and nuclear power. Water energy has also been making a strong come-back after the disastrous experiences with

20 One of the most influential and eloquent advocates of renewable energy has been Hermann Scheer, recipient of the alternative Nobel Prize in 1999, president of the European Association for Renewable Energy, chairperson of the World Council for Renewable Energy, and member of the German parliament for the Social D emocratic Party. His Solare W eltwirtschaft (München: Antje Kunstmann, 1999) has been translated into many languages, and should be required reading for all those who are interested in curbing global warming in a cost-effective and democratic manner. In his article, 'Der Sonnenenergie zum Durchbruch verhelfen', Jahrbuch Ökologie (1997), Scheer effectively deals with a variety of popular misbeliefs regarding the utility of renewable energy.

21 Figures are taken from the website of the U.S. D epartment of Energy: http:eren.doe.gov.

22 See http:/ / www.nrel.gov/ wind/ cost.html.

23 Tom G ray, 'Wind Is G etting Stronger and Is on Course for the Next D ecade', Renewable E nergy W orld (Vol. 2, No. $3,1999)$ 
building mega-dams in a variety of poor countries during the 1970s and 1980s. ${ }^{24}$ For instance, the latest technologies for harnessing tidal energy do not trap fish, while offering inexpensive and reliable energy. Solar energy has also come a long way. The costs of generating electricity with photovoltaic solar cells have fallen some two-hundred to five-hundred times (sic.) since $1980 .{ }^{25}$ It is already profitable to solely rely on photovoltaic energy in many poor, but sunny, areas. This is possible, as the use of photovoltaics enables these areas to avoid the construction of an electricity grid. Moreover, anywhere in the world, photovoltaic systems to generate heat and power can serve as walls and roofs of houses. The costs of doing so are sometimes actually lower than the costs of using traditional construction materials. In addition, the resulting energy costs for households are also lower. ${ }^{26}$ This novel way of constructing houses is therefore also quite promising. Admittedly, a further significant cost reduction (of some 50-75\%) will be needed to make solar energy fully competitive in all parts of the world, and for all possible appliances. But the tremendous and continuous reduction that has already been achieved during the last two decades strongly suggests that this is feasible. With prices having come down, demand has gone up, making it possible to reap economies of scale, and to lower the prices of renewables even more. In Germany, several energy companies now offer electricity that is solely derived from renewable energy resources and that is only slightly more expensive than electricity from conventional sources. In the United Kingdom, the Royal Society for the Protection of Birds (the largest wildlife federation in Europe) offers a similar deal together with a Scottish energy company.

In the transport sector, things have also been moving fast. Almost all major car companies are planning, within the next decade, to mass-produce affordable electric cars that are powered by fuel cells rather than by batteries. ${ }^{27}$ When powered by widely available bioethanol and other types of biomass, these cars would not emit greenhouse gases. The costs of biomass have been halved during the last twenty years, and are expected to dwindle to the production cost of gasoline in some ten to fifteen years time. ${ }^{28}$

24 These disasters are well-documented in the report of the Morse Commission, Sardar Sarovar: Report of the Independent Review (Ottawa: Resource Futures International, 1992); Bruch Rich, Mortgaging the E arth: The W orld Bank, Environmental Impoverishment and the Crisis of D evelopment (Boston, MA: Beacon Press, 1994); and Dipak Gyawali, W ater in N epal (Kathmandu: Himal Books, 2001).

25 See also Peter Marsh, 'Renewable Energy's Renaissance', Financial Times, 29 March 2001.

26 Hermann Scheer, 'Unerschöpflich und sauber: Solarthermische und photovoltaische Energien', A gV Forum (No. 1, 2000), also available at www.hermann-scheer.de.

27 Eugen Hintsches, 'Retten Brenstoffzellen die Mobilität?', Max Planck F orschung (No. 1, 2001), pp. $42-44$.

28 Giuliano Grassi, 'Bioethanol: Industrial World Perspectives', Renewable E nergy W orld (Vol. 3, No. 3, 2000); Hermann Scheer, 'Das unterschätzte Potential der Biomasse und deren Rolle im künftigen Energiemix', Fachzeitschrift: E nergie und Management (November 2000). 
In the somewhat longer term, the sky seems to be the limit. O ne exciting development is (molecular) nanotechnology. ${ }^{29}$ This truly revolutionary way of manufacturing aims to build things atom by atom. These "things" include a mind-boggling array of goods and services. For now, it suffices to know that nanotechnology might enable us to double the energy efficiency of solar cells, as well as to remove contaminants from the air. Furthermore, the continued development of hydrogen may one day allow us to drive a car or fly a plane while producing only drinking water as a by-product.

The rise of the renewables is all the more impressive given the low priority these energy resources have been given over the years. Over $60 \%$ of all energy R\&D undertaken around the world during the last forty years has been spent on developing nuclear energy. In sharp contrast, a meagre $6 \%$ has been used to support renewable energy. ${ }^{30}$ As we now know, the nuclear industry has not been able to offer convincing answers to the questions of what to do with nuclear waste, and how to clean up nuclear plants that are no longer in use. As a consequence, nuclear energy has widely been rejected in both North America and Western Europe. It would indeed not be far-fetched to believe that we would never have got into the current mess in the first place (or at least not to this degree), if the great majority of the world's energy R\&D had not been used to fatten the white elephant called nuclear energy. ${ }^{31} \mathrm{~A}$ more balanced allocation of funds would surely have made the renewables much cheaper by now.

Surprisingly perhaps, this misallocation of funds is still going on. Despite all the rhetoric to the contrary, the public and private funds spent on researching and developing new forms of energy have actually declined in recent years. The painstaking research of James D ooley and his colleagues at the Pacific Northwest National Laboratory has shown that the world's public and private sector investments in energy R\&D have been cut significantly during the last decade. ${ }^{32}$ Moreover, due to worldwide privatisation of energy markets, energy $R \& D$ has increasingly been shifted away from fundamental, long-term projects with distant and insecure pay-offs to low-risk, market-oriented projects. In 1999, in the United States, the Federal Government alone poured about $\$ 40$ billion into military R\&D each year, while both the private and public sectors sprinkled a mere $\$ 4.4$ billion on energy R\&D..$^{33}$ This misallocation of funds borders on the absurd, given the worldwide superiority

29 A useful introduction for lay persons is: K. Eric Drexler and Chris Peterson, with Gayle Pergamit, Unbounding the Future: The N anotechonology R evolution (New Y ork: William Morrow, 1991).

30 The source of these numbers is the Energy Technology R\&D Statistics of the International Energy Agency, available at: http:/ / data.iea.org/ iea/ link_wds.asp.

31 An argument in favour of curbing global warming with an expansion of nuclear energy is Bob van der Zwaan, 'Nuclear Power and Global Warming', Survival (Vol. 42, No. 2, 2000), pp. 61-71.

32 Dooley, Runci and Luiten, op. cit., in note 15.

33 Figure for military R\&D spending taken from John Holdren, 'Energy, Climate and the Human Condition: Meeting the Economic, Environmental, and Security Challenges of Energy Supply in the 21st Century', The CISA C M onitor (Spring 2000), p. 8; figure for energy R\&D spending taken from the website of the Energy Technology R\&D Statistics of the International Energy Agency, op. cit., in note 24. 
of the U.S. military and the very large contribution of America to the greenhouse effect. On the bright side, this misallocation strongly suggests the tremendous potential that renewable energy holds. Starved of funds, the renewables have already gained considerable ground. With a more substantial dose of financial fertiliser, they will bloom.

I do not argue that combating climate change will be painless. A lot of money will have to be spent on breaking our allegiance to fossil fuels. Some industries and regions will suffer and decline as a result. Much infrastructure will need to be changed, and this will be expensive too. But if it were possible to make renewable energy resources cheaper than fossil fuels, and to adapt our modes of transport and production to these novel forms of energy, then we would save ourselves a literally unending stream of money. This point has been overlooked by those who have estimated that the costs of curbing global warming will range in the trillions of dollars. The IPCC has unfortunately bought into this view, thus throwing another log on the fire that has consumed the international politics of climate change. This move has been unnecessary, as it remains fully realistic and attainable to sink the costs of renewable energy below the costs of energy generated from fossil fuels. ${ }^{34}$ This is a realistic goal in view of the impressive progress that the renewables have already made during the last twenty years - against all odds. Moreover, there is much that governments and citizens can do to induce businesses to bring about this state of affairs.

\section{A Snowball against Global Warming}

How can governments trigger the quest for technologies and energy resources that are both cheaper and cleaner? Clearly, government expenditures on energy $R \& D$ need to be vastly increased. The present decline in public funding for energy projects should immediately be reversed. A couple of principles need to be followed when doling out this extra money. First, increased public funding should not diminish private investments in energy R\&D. Second, it is vital not to put all public eggs into one basket. This, essentially, was the blunder of post-war energy policy around the world, gambling everything on nuclear energy. A wide variety of renewable energy resources and novel technologies should be supported, including some seemingly crazy schemes and far-out plans. Forms of energy and technology that would not only be climate-friendly, but would alleviate other environmental problems as well, should be promoted in particular. Third, it is imperative not to channel all public funds through a single department or organisation. Allowing a diversity of

34 In terms of the models that have been built to predict the costs of combating climate change, I am siding here with the conclusions that follow from "bottom-up models", and against the results of "top-down models". For this distinction, as well as a useful overview of the literature on modelling the costs of climate change, see Jae Edmonds, Joseph M. Roop and Michael J. Scott, Technology and the E conomics of Climate C hange (Washington, DC: Pew Center on G lobal Climate Change, 2000). 
departments to allocate funds for energy R\&D would be another check on organisational myopia. Given the rapidly accumulating evidence of climate change, there is no time left to raise and nurture any more white elephants.

Governments can also do much to stimulate private investments in energy R\&D. Moral persuasion can play an important role. Many empirical studies have shown that especially in Western Europe and Eastern Asia corporations are not single-minded profit-seekers without any regard for the environment. ${ }^{35}$ When corporate leaders in these countries are offered conclusive evidence that their companies pollute the environment, they often attempt to change their ways. Therefore, engaging in a dialogue with industry leaders and environmental activists on the need to develop forms of energy and technology that do not emit greenhouse gases will probably have a significant impact.

But it will not be necessary to merely tread softly. A big stick can also be wielded by governments interested in curbing climate change. The energy prices on the world markets are neither divinely ordained, nor the natural outcome of unperturbed market forces. Energy prices are heavily influenced by existing infrastructure for producing, distributing and consuming energy, such as electricity grids. They are also dependent on many public institutions, including government regulation of energy markets, patenting rights, as well as taxes and subsidies. All of this gives governments quite a bit of influence over energy prices. At present, many government regulations and much infrastructure still rig the competition in the energy markets in favour of fossil fuels. An astonishing example of this is the $\$ 300$ billion that governments all over the globe spend each year on subsidies for the use of fossil fuels. The European Union alone sponsors the use of the most polluting fuel, coal, with an annual $\$ 10$ billion. ${ }^{36}$ As a start, this playing field should be levelled as soon as possible.

The literature on innovation offers some insight on how technological growth can be stimulated ${ }^{37}$ If governments want to promote innovation within firms and sectors, they have to allow for a

35 Joseph L. Badaracco, Loading the Dice: A Five-Country Study of Vinyl Chloride Regulation (Boston, MA: Harvard Business School Press, 1985); Ronald Brickman, Sheila Jasanoff and Thomas Ilgen, Controlling Chemicals: The Politics of Regulation in Europe and the United States (Ithaca, NY: Cornell University Press, 1985); Graham Wilson, The Politics of Safety and Health (Oxford: Clarendon Press, 1985); David Vogel, National Styles of Regulation (Ithaca, NY: Cornell University Press, 1986); Robert A. Kagan and Lee Axelrad, 'Adversarial Legalism', in Pietro S. Nivola (ed.), Comparative Disadvantages? Social Regulations and the Global Economy (Washington, DC: Brookings Institution Press, 1997); Lyle A. Scruggs, 'Institutions and Environmental Performance in Seventeen Western Democracies', British Journal of Political Science (Vol. 29, No. 1, 1999), pp. 1-31; Marco Verweij, 'Why Is the River Rhine Cleaner than the Great Lakes (Despite Looser Regulation)?', Law \& Society Review (Vol. 34, No. 4, 2000), pp. 501-48.

36 Hermann Scheer, 'Mit Solarenergie zu einer ökologischen industriellen Revolution', G ewerk schaftliche Monatshefte (March 1996), also available at www.herman-scheer.de; and Richard L. Ottinger and Mindy Jayne, G lobal Climate ChangeKyoto Protocol Implementation: Legal Frameworks for Implementing Clean Energy Solutions, available at www.solutions-site.org.

37 See Arie Rip and René Kemp, Technological Change', in Steve Rayner and Elizabeth L. Malone (eds), H uman Choice \& Climate Change, V olume 2: Resources and Technology (Columbus, OH: Batelle Press, 1998). 
minimum of "sheltered competition". In the energy markets, governments can offer such shelter to enterprises that are developing renewable energy resources by giving tax breaks, offering subsidies, revamping infrastructures and protecting patents. Given the large pool of opportunities to make clean sources of energy economically viable, these government measures would offer quite a few enterprises strong financial incentives to plunge headlong into the development of renewable energy resources. An example of an effective domestic policy is the "100,000 Roof Photovoltaic Programme" that the G erman federal government started in 1999.

Thus, a snowball-effect against global warming can be created. When it becomes clear that certain companies are well on their way to developing and deploying clean technologies and energy resources that are cheaper than existing dirty alternatives, then a mad rush to imitate will follow. For clear-cut financial reasons, it will be imperative for sluggish competitors to scramble upon the bandwagon. If Shell and British Petroleum started to conquer the world's energy markets with cheap renewables, then Exxon would have to follow suit or perish. If the German electricity company Eon-Aquapower undercut the prices of its competitors that had kept on using fossil fuels to generate electricity, then the latter would have little time left to change course. The same might apply at the country-wide level. If the oil-producing countries realised that other states are sincerely committed to developing affordable and clean energy, then they would have to quickly develop cheap methods to decarbonize fossil fuels, or invest heavily in other forms of energy, or else bite in the sand. Along these lines, a tiny snowball made up of a few companies and sectors here and there could grow in size very quickly, and have a tremendous impact on our efforts to curb global warming.

How could international cooperation speed up this ever-increasing snowball against global warming? It would be helpful if the OECD countries agreed on stringent goals for the reduction of greenhouse gases. But these goals should be seen as targets that government will strive to reach, and not as legally binding international agreements. In this way, the legal bickering that typically befuddles international treaties could be skipped. It would also allow for the formulation of much more ambitious goals than has thus far been the case. These ambitious aims should be based on the cutbacks in greenhouse gases that scientists deem necessary for the stabilisation of our atmosphere, rather than on what might look "politically acceptable" to exhausted diplomats during the last few hours of an international conference. Moreover, having a set of very strict international norms would stimulate technological change. Technological innovation is an inherently risky process. It is therefore crucial to those who are contemplating investing in new technologies that the authorities will not waver in their support of these technologies. A strict international agreement on the 
reduction of greenhouse gases would flag to enterprising firms that the governments were serious about combating global warming.

Intergovernmental agreement on funding energy $R \& D$ would also be beneficial. This would not be strictly necessary, and should certainly not be subject to any legal obligations. However, it would ratchet up the R\&D budgets of various countries that did not want to be seen as profiteers, or that worried about missing out on the latest technological developments. An international agreement on funding energy R\&D would ideally be concluded by the finance ministers of the involved countries, in collaboration with the environment ministers. (On occasion, international measures against climate change agreed upon by the environment ministers of the European Union were later rejected by their colleagues from the finance ministries).

The biggest role for international cooperation in the fight against global warming lies in assisting developing countries to acquire low-cost technologies and energy resources that do not emit greenhouse gases. Any attempt to transfer climate-friendly technologies will founder, if those technologies are not affordable or do not solve more pressing environmental problems in developing countries. However, even if such technologies became available a lot of work should still be done. Access to information on these technologies should be improved. Furthermore, developing countries should be assisted in making the institutional and infrastructural changes that are necessary to accommodate these new technologies. And local capacities to produce new forms of energy and technologies should be aided. The International Atomic Agency and the OECD (through its Climate Technology Initiative) have already initiated a lot of good work in this regard. Yet again, diversity should be the watchword. A patchwork of governmental and private organisations should be involved in technology transfer. Multilateral as well as bilateral forms of cooperation should be encouraged. The developing countries are so diverse and numerous that a single, universal transfer mechanism would undoubtedly fail. The World Bank's "Global Environmental Facility" should only play a limited role.

Already in 1990 Henk Tennekes, Director of Research at the Royal Netherlands Meteorological Institute, warned against founding our efforts to combat global warming on "technocratic totalitarianism" ${ }^{38}$ In recent years, more and more people have concluded that Tennekes's timely warning has unfortunately not been heeded by international policy-makers. Earlier this year, Member of the German Parliament Hermann Scheer chided the Kyoto Protocol for promoting "Totalbürokratismus", David Victor wrote about "Kyoto's Fantasyland", and Ronald Brunner deplored the "technocratic hubris" that pervades the current international negotiations on climate

38 Henk Tennekes, 'A Sideways Look at Climate Research', W eather (Vol. 45, 1990), pp. 67-68. 
change. ${ }^{39}$ From the viewpoint of the theory of public policy, the UNFCCC/ Kyoto Protocol relies almost exclusively on a single way of solving public issues: a bureaucratic, top-down, hierarchical way of making public policy. This is unfortunate, as an increasing number of public policy-specialists have been taking up the conclusion that social problems can only be satisfactorily solved by a creative combination of different modes of policy-making. ${ }^{40}$ This essay does therefore not make the argument that "unfettered markets will by themselves counter the threat of global warming, due to the great commercial promise of renewable energy". This promise certainly exists, but can only be fully and swiftly tapped when domestic and international government programs and regulations are combined with the power of market forces.

39 Interview with Hermann Scheer by Daniel Freudenreich in Berliner M orgenpost (23 July 2001) entitled 'Alternativer Nobelpreisträger warnt vor einer Totalbürokratisierung des Klimaschutzes'; D avid Victor, op. cit., in note 10, chapter 2; and Ronald D. Brunner, 'Science and the Climate Change Regime', Policy Scienos (Vol. 34, No. 1, 2001), p. 26.

40 See, for instance, Christopher Hood, The A rt of the State (Oxford: Clarendon Press, 1998); as well as Michael Thompson and Steve Rayner, 'Risk and Governance; Part I: The Discourses of Climate Change', G overnment \& 0 pposition (Vol. 33, No. 2, 1998), pp. 139-66; and Michael Thompson, Steve Rayner and Stephen Ney, 'Risk and Governance, Part II: Policy in a Complex and Plurally Perceived World', G overnment \& 0 pposition (Vol. 33, No. 3, 1998), pp. 330-54. 